\title{
SMALL CLAIMS AND PROCEDURAL SIMPLIFICATION: EVIDENCE FROM SELECTED EU LEGAL SYSTEMS
}

\author{
Elisabetta Silvestri \\ PhD in Law, ass. prof. of Italian Civil Procedure; \\ Comparative Civil Procedure; \\ Arbitration and Mediation, \\ University of Pavia (Pavia, Italy)
}

Summary: 1. Introduction. - 2. France: Simplified Procedures for the Recovery of Small Credits. - 3. Spain: Juicio Verbal and Monitorio Notarial. - 4. Italy: the Justices of the Peace. - 5. Concluding Remarks.

Most legal systems have a long-standing tradition of simplified procedures for the disposition of small claims. Obviously, the elements that qualify a claim as 'small' vary: the most significant one, meaning the amount of money at stake, reflects the economic situation of a given country. In any event, and regardless of the maximum sum that can be recovered, small claims are the claims that are most important to ordinary citizens. For if people had to turn to full-fledged litigation, probably many would relinquish their rights, being unable to bear the costs and the delays of a traditional judicial procedure. That is the reason why legal systems should provide inexpensive and expedited procedures for small claims if they really want to fulfil the promise of access to justice for all.

This essay examines the solutions adopted in France and Spain, pointing out that the use of easily available forms can make a big difference, as can also the accessibility of IT platforms specifically designed for the recovery of small credits. The state of affairs in Italy for simplified procedures for small claims is also addressed through a description of the jurisdiction of the Italian justices of the peace.

Key words: small claims; simplified procedure; access to justice; forms; IT platforms.

\section{INTRODUCTION}

The anonymous author of an essay published in an American Law Journal in 1924 wrote that, 'A small claims court is doomed to failure unless it can speedily bring its cases to a final determination.' ${ }^{1}$ Further on in the essay, the reader can find a

1 Anonymous, Small Claims Procedure is Succeeding (8 J Am Jud Soc 1924) 247, 248. 
detailed list of the procedural features that are deemed to be essential for the swift disposition of small claims: an informal and untechnical procedure; a judge acting as 'an impartial investigator into the truth', being in affirmative control of the whole proceeding ; ; and the possibility for the parties to appear in court without the representation of lawyers, since "it is desirable that lawyers should not commonly appear because it is desirable that the expense of their appearance should be avoided".

It is astonishing to discover that almost a century ago scholars were already debating over the need to provide for procedural models suitable for small claims, so that one may be inclined to think that nothing new is invented when contemporary lawmakers provide for simplified procedures aimed at granting small claims an expedited, inexpensive but also fair treatment in court. More or less, all European Union legal systems deal with small claims in specific ways, sometimes allocating them to special judicial bodies (for instance, small claims courts or courts operated by lay judges), other times relying on procedural rules that are different from the ones followed before the ordinary courts of first instance. Alongside national procedures, the European Small Claims Procedure (hereinafter ESCP) ${ }^{4}$ exists for cross-border cases, so that two parallel procedures (the national one and the European one) are available for small claims that meet the requirements for the application of the European instrument at the choice of the plaintiff.

This essay will not deal with the ESCP even though it is a piece of European legislation specifically aimed at devising a uniform, simplified procedure for the recovery of small claims across Member States. A recent, comprehensive study has analysed the ESCP in depth, clarifying the background of the Regulation, its purposes and shortcomings, and therefore this author does not consider it necessary to repeat concepts that have been masterfully expounded by someone else. ${ }^{5}$ Furthermore, the optional nature of the ESCP is such that its actual application, at least in some Member States, is negligible. This is the case, for instance, in Italy, where the practical relevance of the ESCP is inversely proportional to the theoretical commentaries on the Regulation produced by Italian scholars. ${ }^{6}$

In addition to Italy, the legal systems that this author has chosen for her analysis of simplified procedures for the disposition of small claims are those of France and Spain. This choice does not signify a value judgment, since a value judgment is not possible when looking at the two national procedures from a distance and without the benefit of empirical data. That said, the impression of a foreign 'bystander' is that both the French and the Spanish procedures are (at least, in theory) efficient, simple and with a touch of modernity that potentially will make them even more accessible to individuals. After all, the ability of a legal system to grant access to justice across the board is

2 Id 251.

3 Id 252

4 Regulation (EC) No 861/2007 of the European Parliament and of the Council of 11 July 2007 establishing a European Small Claims Procedure, OJ L 199, 31.7.2007, 1-22; Regulation (EU) 2015/2421 of the European Parliament and of the Council of 16 December 2015 amending Regulation (EC) No 861/2007 establishing a European Small Claims Procedure and Regulation (EC) No 1896/2006 creating a European order for payment procedure, OJ L 341, 24.12.2015, 1-13 (in force since 2017).

5 Reference is made to E A Onțanu, Cross-Border Debt Recovery in the EU: A Comparative and Empirical Study on the Use of the European Uniform Procedures (Intersentia 2017).

6 See E Silvestri, 'Italy: Simplification of Debt Collection in Italy - National and EU Perspectives', in V Rijavec, et al (eds), Simplification of Debt Collection in the EU (2014) 347-61. 
tested not with respect to cases where the amount at stake is large and the parties have all the resources (financial, social and cultural) necessary to navigate complex, costly and long court procedures, but with respect to cases where the amount at stake is small.

\section{FRANCE: SIMPLIFIED PROCEDURES FOR THE RECOVERY OF SMALL CREDITS}

As far as France is concerned, a detailed study of the procedures provided for the disposition of claims whose value is limited should entail an analysis of a variety of proceedings available before the Tribunaux d'instance, meaning the courts of first instance whose jurisdiction includes claims up to the value of $€ 10,000 .^{7}$ As a matter of fact, the French Code of Civil Procedure contemplates four different proceedings that can be lodged with a Tribunal d'instance. Out of these proceedings one seems particularly interesting, since it concerns claims that, at least from the point of view of this author, can truly be deemed small. For claims not exceeding the value of $€ 4,000$, the plaintiff can choose to resort to a simplified procedure that entails a simple déclaration au greffe, meaning a statement addressed to the court's clerk who provides for its registration. ${ }^{8}$ The statement can be made orally or in written form. In any event, the statement must meet the general requirements specified by the Code for the introductory pleading before any civil jurisdictions and a summary explanation of the cause of action supporting the claim. The déclaration au greffe can be made also by filling in a form that can be downloaded from a number of websites managed by the French public administration. ${ }^{9}$

One peculiar feature of this procedure is that a preliminary attempt at conciliation is mandatory. Actually, the duty of the plaintiff to explore possible ways to reach a settlement with his adversary has a general character, since the introductory pleading of all cases lodged with any courts of first instance must mention 'the diligences taken with a view to reaching an amicable resolution of the dispute' (my translation). ${ }^{10}$ When this rule was adopted in 2015 in furtherance of the recourse to ADR methods, failure to comply with the duty to attempt conciliation or other forms of peaceful resolution of the dispute was not sanctioned, and probably one reason for that was the fuzziness of the concept of acceptable 'diligences' suitable

$7 \quad$ Until 1 July 2017, claims up to $€ 4,000$ belonged to the jurisdiction of the juges de proximité, lay judges established in 2002 and considered, rightly or wrongly, the heirs of the traditional justices of the peace. They have been repealed from the French judicial geography, since their operation had never been satisfactory and their establishment has often been seen by stakeholders as a useless factor of complication in the identification of the appropriate court of first instance: see Commission sur la répartition des contentieux présidée par Serge Guinchard, Rapport au Garde des Sceaux: L' ambition raisonnée d'une justice apaisée 204204 (La documentation Française 2008). On the 'philosophy' supporting the establishment of community justice in France, see $M$ Vericel et al, Juridictions et juges de proximité : leur rôle concret en matière d'accès à la justice des petits litiges civils [Rapport de recherche] (2008) <https://halshs.archives-ouvertes.fr/file/index/ docid/946154/filename/Rapport_annexes_Juges_de_proximite.pdf> accessed 1 November 2018.

8 See arts 843-844 of the French Code of Civil Procedure.

9 For instance, one address is <https://www.formulaires.modernisation.gouv.fr/gf/cerfa_11764. do. $>$ accessed 1 November 2018.

10 See arts 56, s 3, and 58, s 3. of the French Code of Civil Procedure, as modified by art 18 of the decree no 2015-282 of 11 March 2015 (Décret $n^{\circ}$ 2015-282 du 11 mars 2015 relatif à la simplification de la procédure civile à la communication électronique et à la résolution amiable des différends). 
to put an end to the controversy. But a statute passed in 2016 reinforced the duty, ${ }^{11}$ providing for a harsh sanction in case of failure to comply with it: if a preliminary attempt at conciliation has not taken place, the Tribunal d'instance, even ex officio, can declare the case inadmissible, unless some special circumstances occur, for instance when the parties can give proof that they have carried out other 'diligences' with a view to reaching a mutually acceptable solution of their dispute.

If the attempt at conciliation is unsuccessful, the case can proceed according to the rules governing contentious procedure. A hearing is set for the parties to appear in person or, if they wish, by a representative (for instance, a family member), since the assistance of council is merely optional. The proceeding is oral, at least in principle. It is up to the judge to attempt again the conciliation of the parties or to delegate this task to a conciliateur de justice, who is a judicial officer whose specific task is to help the parties reach a settlement, under a duty of impartiality and confidentiality. If an agreement is reached, it will be made enforceable by the judge; otherwise the proceeding will end up with a judgment that can be appealed against, not before the intermediate court of appeal, but only before the French Supreme Court, that is, the Cour de cassation. ${ }^{12}$

Since 1 June 2016 a new, simplified procedure for the recovery of small claims has been in operation. ${ }^{13}$ The creditor can avoid any judicial proceeding by simply resorting to a bailiff, provided that the credit does not exceed $€ 4,000$ and arises out of contracts or statutory obligations. Special rules determine which bailiff can be in charge of the procedure, but the interesting thing is that the creditor can petition the bailiff by means of a simple letter, a verbal statement or via electronic communication. Actually, all the exchanges between the bailiff and the parties can take place via an IT platform devoted to the recovery of small credits. ${ }^{14}$

The bailiff bears the responsibility of the whole procedure: he informs the debtor of the request made by the creditor and invites him to take part in the simplified procedure. Thanks to the bailiff's good offices, the parties are expected to reach an agreement on the amount to be recovered and the terms of payment. If an agreement is reached, the creditor receives from the bailiff an enforceable title that he will be able to use for the recovery of the money owed to him, should the debtor fail to honour the agreement. If the debtor fails to accept the invitation to take part in the simplified procedure or if no agreement is reached by the parties, the bailiff acknowledges the defeat of the procedure, and the creditor will be forced to resort to a contentious procedure for the recovery of his claim. ${ }^{15}$

11 See art 4 of the statute no 2016-1547 of 18 November 2016 (Loi $n^{\circ}$ 2016-1547 du 18 novembre 2016 de modernisation de la justice du XXIe siècle).

12 See S Guinchard et al, Procédure civile (3d ed Dalloz 2013) 42634.

13 This procedure was introduced by the decree no 2016-285 of 9 March 2016 (Décret $n$. 2016-285 du 9 mars 2016 relatif à la procédure simplifiée de recouvrement des petittes créances).

14 The platform (website) is accessible via the following addresses: <https://www.petitescreances.fr/ and https://www.credicys.fr/> accessed 2 November 2018. The website is managed by the National Association of Bailiffs (Chambre nationale des huissiers de justice). See the order issued by the Ministry of Justice on the establishment of the platform: Arrêté du 3 juin 2016 relatif à la mise en oevre par voie électronique de la procédure simplifiée de recouvrement de petites créances, available at $<\mathrm{https}$ ://www.legifrance.gouv.fr/ affichTexte.do?cidTexte=JORFTEXT000032657522\&categorieLien=id.> accessed 1 November 2018.

15 See arts R125-1-125-6 of the Code des procédures civiles d'exécution. 
The advantages of the procedure managed by bailiffs are several. The fact that the whole procedure can be conducted online, simply by filling in a few forms that are easy to access on a secure website, means a considerable savings in terms of time, which is made even more attractive if one keeps in mind that the debtor has only one month to decide whether or not he is willing to agree to take part in the simplified procedure. Another positive feature of the procedure is the reduced cost: when the creditor turns to the bailiff and the procedure begins, a payment of $€ 14.92$ is required. If the procedure is unsuccessful, no further fees are due. If, on the contrary, the parties reach an agreement, $€ 30$ will be charged to the creditor for the delivery of the enforceable title. Furthermore, a modest amount of money will have to be paid by the creditor as remuneration for the bailiff who managed the procedure: the remuneration is calculated by applying specific ratios to the amount of the recovered credit. In any event, the total cost of the procedure is truly reasonable, as it should always be for the disposition of small claims that are likely to be relinquished if the legal costs associated with their recovery are bound to exceed their value, which still happens - unfortunately - in some legal systems.

\section{SPAIN: JUICIO VERBAL AND MONITORIO NOTARIAL}

For claims whose value does not exceed the threshold of $€ 6,000$ the Spanish Code of Civil Procedure (in Spanish, Ley de enjuiciamiento civil, hereinafter LEC) provides for a simplified procedure called juicio verbal (oral proceeding). ${ }^{16}$ As its denomination makes clear, it is a proceeding that is conducted orally before the judge, at least in principle. Better yet, the orality of the procedure was its main feature in the original version of the LEC, passed in 2000. At present, due to the reforms adopted in 2015, the oral character of the procedure appears to be diluted in favor of more formal and written procedural steps.

The complaint lodged by the plaintiff is written, but if the amount at stake does not exceed the sum of $€ 2,000$ the Code allows a 'succinct demand' (my translation of the Spanish demanda sucinta), with the basic information concerning the identity of the parties, the remedy sought and the facts constituting the cause of action. Alternatively, the plaintiff can resort to standardized forms that can be downloaded from the website of the Spanish General Council of the Judiciary. It is worth noting that below the value of $€ 2,000$ the assistance of attorneys is merely optional, which makes understandable the reasons why the statement by which the court is petitioned can have a simple outlook or consist in a standardized form.

Before 2015, the defendant's answer to the plaintiff's complaint could be presented orally at the hearing. This feature of the juicio verbal made sense in the context of a procedure whose tenets were the principles that are normally associated with orality, meaning the principles of concentration and immediacy (the latter suggesting that the judge in charge of deciding the case must be the one in charge of the taking of evidence, too). In spite of that, it was widely accepted that this very feature was

16 See arts 437-447 of the LEC. On the juicio verbal, see, for instance, José Garberí Llobregat, El nuevo juicio verbal En la Ley de Enjuiciamiento Civil (Bosch 2015); A José Vélez Toro 'El juicio verbal y la tutela judicial efectiva: Desajustes del modelo establecido en la Ley de Enjuiciamiento Civil' (2016) 9 Revista de Paz y Conflictos 263, 263-96. 
prejudicial for the plaintiff, since he was able to gain knowledge of the defences of his opponent only at the hearing: a surprise effect deemed detrimental to the right of action and defence enshrined in article 24, section 1 of the Spanish Constitution. ${ }^{17}$ The reforms of 2015 have radically changed the situation: now the defendant must lodge a written answer in which he is expected to disclose all his defences. As for the plaintiff, if the value of the claim does not exceed the amount of $€ 2,000$ and therefore the assistance of an attorney is not mandatory, the defendant, too, can prepare his answer relying on a standardized form to be filled in.

Another far-reaching change brought about by the reforms of 2015 is the fact that the hearing will take place only insofar as the parties request (or, at least one party requests) the holding of the hearing. Therefore, the possibility exists that if the parties waive their right to a hearing, the proceeding will end up being exclusively written. Of course, the mutation of the juicio verbal into a written proceeding, lacking the 'event' that was considered its most important feature, that is, the hearing (vista in Spanish) devoted to the clarification of the factual terms of the dispute, the taking of evidence and the final arguments of the parties, seems almost a contradiction in terms. In spite of that, the text of the relevant rule is unambiguous where it provides that if neither party requests a hearing nor does the judge deem it necessary, the judgment on the case will be rendered immediately, presumably on the sole base of the plaintiff's complaint and the defendant's answer, without any further exchange of pleadings or procedural steps. ${ }^{18}$ At the same time, it is hard to deny that for small claims, and especially for those that, due to their limited value, can be litigated by the parties in person, a written procedure that can be conducted simply by filling in ready-made forms is probably the best course of action. After all, even the ESCP, which is supposed to be the archetype of a simplified procedure aimed at granting access to justice in expedited and inexpensive ways, is designed as 'essentially a written procedure. Oral hearings should only be held exceptionally where it is not possible to give the judgment on the basis of the written evidence or where a court or tribunal agrees to hold an oral hearing upon a party's request.' ${ }^{19}$

Returning to the Spanish juicio verbal, if the hearing does take place, the LEC contemplates the possibility that the parties inform the judge that they have already reached an agreement or 'show their willingness to reach an agreement' (my translation). ${ }^{20}$ It is possible, too, that the proceeding is stayed, should the parties express their common intention to attempt mediation. If a settlement is submitted to the judge, he can homologate it, which means to make the agreement an enforceable instrument. If no settlement is reached by the parties either in court or out of court, the procedure will continue with the taking of evidence and a round of final arguments. Afterwards, the judge will issue the judgment, which is subject to appeal, provided that the value of the claim is above the amount of $€ 3,000{ }^{21}$

17 Art 24, s 1 reads: 'Every person has the right to obtain the effective protection of the Judges and the Courts in the exercise of his or her legitimate rights and interests, and in no case may he go undefended.' This is the official translation into English of the Spanish Constitution of 1978, available at <http://www.congreso.es/constitucion/ficheros/c78/cons_ingl.pdf.> accessed 13 October 2018.

18 See, in particular, art $438, \mathrm{~s} 4$ of the LEC

19 See recital no 11 of Regulation (EU) 2015/2421, supra note 4.

20 See art 443 of the LEC.

21 See art. $455 \mathrm{~s} 1$ of the LEC. 
Since 2015, another simplified procedure for the recovery of money claims has been in operation. This procedure does not specifically concern small claims, because it is available for any money claims, no matter what their value is, provided that the claim is uncontested. The procedure, called monitorio notarial, is managed by notaries public and, because of that, can be defined as an out-of-court, non-judicial procedure. ${ }^{22}$ It does not seem necessary to describe in detail the various steps of the procedure, which begins with an oral application lodged by the creditor upon presentation of the documents necessary to demonstrate that the credit exists 'beyond any doubts' (my translation of the Spanish la deuda ... sea indubitada). The notary will make delivery to the debtor of a formal request to pay the amount due within a short deadline (twenty days). The procedure is successful if the debtor meets with the notary and pays the amount due, keeping in mind that the debtor may appear before the notary for the sole purpose of challenging the claim, which will put an end to the notarial procedure and force the creditor to explore the regular judicial avenues to recover his claim. Furthermore, for the positive outcome of the procedure it is essential that the location of the debtor is known to the creditor, since the notary public is devoid of any powers of investigation as to the debtor's whereabouts. If the debtor does not meet with the notary or shows up, but neither pays nor challenges the claim, the notarial deed attesting the failure of the procedure will work as an enforceable instrument that the creditor will be able to use for the recovery of his credit according to the ordinary enforcement procedures.

The procedure managed by notaries public is quite informal, in view of the fact that the parties do not have to be assisted by their attorneys, and it is deemed the fastest and least expensive one among the different proceedings provided by Spanish law for the recovery of money claims. These very features, of course, are important most of all for small claims even though the odds of a failure of the procedure if the debtor does not pay or is nowhere to be found seem particularly high. ${ }^{23}$

\section{ITALY: THE JUSTICES OF THE PEACE}

The Italian legal system does not provide for any simplified procedures for small claims. Claims up to the value of $€ 5,000$ belong to the jurisdiction of the justices of the peace, who are lay judges placed at the bottom of the judicial pyramid. The problem is that their jurisdiction shoots up to $€ 20,000$ for claims concerning the

22 The procedure is governed by arts $70 \& 71$ of the Notarial Law, as amended by the statute on non-contentious jurisdiction adopted in 2015 (Ley 15/2015, de 2 de julio, de la Jurisdicción Voluntaria). The text of the Notarial Law (in Spanish) can be accessed at <https://www.boe.es/ buscar/pdf/1862/BOE-A-1862-4073-consolidado.pdf.> accessed 13 October 2018. On the new procedure, see, for instance, J Bonet Navarro, 'Reclamacion de deudas dinerarias no contradichas a traves de notario (uno instrumento entre la deficiencia y la eficacia)' (190) noviembre 2016 Revista Ceflegal 1-38. available at <https://www.uv.es/ ripj/obraspdf/Reclamaci\%C3\%B3n\%20 deudas\%20dinerarias\%20no\%20contradichas\%20a\%20trav\%C3\%A9s\%20de\%20notario.pdf > accessed 3 November 2018; J Banacloche Palao 'Los Nuevos Expedientes y Procedimientos de Jurisdicciyn Voluntaria’ (2015) 15 Analisis de la Ley 259-62.

23 For this opinion, see R Jan-Sánchez, 'Small Value Claims and Digital Justice in Spain: Cost and Efficiency', (2017) 2 International Journal of Procedural Law 250, 260. 
recovery of damages caused by traffic accidents. ${ }^{24}$ Therefore it would be incorrect to identify the offices of justices of the peace as the small claims courts of Italy, also keeping in mind that whatever the amount at stake is, the procedure stays the same, with no simplified features for claims whose value is limited. It is true that below the threshold of $€ 1,100$ the parties can litigate in person, ${ }^{25}$ but this is the sole saving grace of a procedure that is only a 'variation on the theme' of the ordinary procedure before the courts of first instance, whose rules apply insofar as the Code of Civil Procedure does not dictate any special regulations.

The future does not look bright for small claims in Italy. According to a statute that was passed in 2017, but will enter into force in 2021, the jurisdiction of the justices of the peace will increase dramatically, reaching the amount of $€ 30,000$ or $€ 50,000$ depending on the cause of action of the claim. ${ }^{26}$ It is true that what makes a claim 'small' can vary according to an array of factors, but nobody can deny that a claim worth tens of thousands of euros is anything but a small claim. In any event, the future reform will increase the jurisdiction of justices of the peace without modifying the rules governing the procedure and, most of all, without providing for a real simplified procedural path for small claims. Another missed opportunity of the prospective reform is the lack of any reference to any easily accessible, standardized forms to be used at least for the cases that the parties can litigate in person.

Presently, the procedure before the justices of the peace is mainly written, even though (at least in theory) some room is left for orality. For instance, the complaint can be lodged verbally, in which case it is recorded by the judge, who also takes care of the serving of the complaint on the defendant. ${ }^{27}$ Needless to say, in the contemporary practice and procedure before the justices of the peace oral complaints are unheard of. Similarly, at the hearing the justice of the peace is supposed to question the parties in order to gain first-hand knowledge of the facts in dispute and with a view to attempting their conciliation. ${ }^{28}$ This oral dialogue between the parties and the judge is more often than not a mere formality, or a step that the judge can avoid with the certainty that his omission will not be sanctioned.

All in all, one could venture to say that the Italian legislators do not show any interest in providing expedited and inexpensive judicial procedures for small claims, probably with the hope that the many mandatory forms of ADR that are in operation are sufficient to satisfy the need for access to justice for those who will end up relinquishing their claims rather than facing the delays and costs of litigation. ${ }^{29}$ According to widespread public opinion, resorting to ADR is anyway better than doing nothing, even

24 Art 7, ss. 1 \& 2 of the Italian Code of Civil Procedure.

25 See art $82 \mathrm{~s} 1$ of the Italian Code of Civil Procedure.

26 The reform, which not only raises the financial value of the claims, but also extends the jurisdiction of the justices of the peace to a number of enforcement procedures and a few non-contentious proceedings as well, was adopted by legislative decree no 116 of 13 July 2017.

27 See art 316, s 2 of the Italian Code of Civil Procedure.

28 See art 320, s 1 of the Italian Code of Civil Procedure.

29 On the development of ADR methods in Italy with a confusing alternation between a mandatory and an optional character of the means that can be chosen to settle disputes, see E Silvestri, 'Too Much of a Good Thing: Alternative Dispute Resolution in Italy' (2017) 21 (4) Nederlands-Vlaams tijdschrift voor Mediation en conflict management 77-90. 
though what you get is often less than (or different from) what you really wanted to obtain, due to the fact that you must somehow compromise in order to reach an agreement with your opponent. One may subscribe to this point of view and think that it is just a different form of access to justice, a justice that it is not the traditional, classic one dispensed by the courts of law, but a multifaceted, informal justice that opens up a kaleidoscope of avenues for the vindication of one's rights. All of that may be true, but this author is proud to be old school in her belief that one of the duties of a State is to provide access to the court system without 'outsourcing' the administration of justice.

\section{CONCLUDING REMARKS}

The closing sentences of an essay on small claims published almost twenty years ago by two American authors read as follows: 'Those in the legal community who share our commitment to a civil justice system that truly serves all American should join the reform efforts to expand and improve small claims courts. It really can make a difference. ${ }^{30}$ Indeed, the treatment of small claims, whether through specialized courts or simplified procedures or a combination of both, is one of the test benches of a given legal system and its ability to satisfy the needs of ordinary citizens. In this regard, an interesting list of 'general guidelines' for the appropriate resolution of small claims can be found in the same essay mentioned above: no attorneys for the parties; sample forms to be filled in for the complaint of the plaintiff and the answer of the defendant; simplified rules of evidence; a single hearing held within a short time after the suit has been filed; and a decision issued at the closing of the hearing itself or announced within a few days. What seems critical is to avoid that the court in charge of small claims becomes solely 'a debt collection agency where businesses routinely turn bad debts into uncontested judgments and individuals rarely participate as anything other than defendants. ${ }^{31}$ Furthermore, while the claims may have a limited monetary value, this does not necessarily mean that they deal with uncomplicated and trivial issues. All of this must be taken into account in designing procedures that are simple, fast and inexpensive, but also able to guarantee to individuals the appropriate remedies for their legal problems.

November 3, 2018

30 J C Turner, J A McGee, 'Small Claims Reform: A Means of Expanding Access to the American Civil Justice System’ (2000) 5 UDC L. Rev 177, 188.

31 S McGill, 'Small Claims Court: A Vehicle for Social Change and the Case for Equitable Relief' (2017) 26 JL \& Soc Pol'y 90, 90-91. 